\title{
THE MUDEJARS OF THE CROWN OF ARAGON IN THE EARLY DOCUMENTS OF JAUME THE CONOUEROR (1218-1227)
}

Por

CHRISTOPHER DAVIS

The historiography of the Mudejars or conquered Muslims of Medieval Christian Spain suffers from several lacunae. One such lacuna is Mudejar history for Mediterranean Spain from 1196 to 1229 -- that is, from the beginning of the reign of Pere the Catholic up to the beginning of the crusade against Islamic Majorca undertaken by his son and successor Jaume the Conqueror. A deficiency of published documents, including a mere scattering of documents for Pere's reign, accounts for this gap (1). For the reign of King Jaume we do have the pre-World-War I collection by Ambrosio Huici (2), now reappearing slowly in a somewhat expanded form by M. D. Cabanes Pecourt (3). This collection allows the scholar just a peek at the Mudejars of these realms during the early years of Jaume. The corpus was gathered mostly from published sources, it must be remembered, and does not include all of those. It begins in 1216, automatically excluding the first three years of Jaume's reign. No one has yet examined the collection systematically for the early Mudejar years.

The earliest Mudejar document there dates from 1218 and the last in our pre-Majorca set from 1227, thus spanning ten years. Out of a total 115 charters

(1) An elaborate annotated bibliography is now available on the Muslims and Mudejars of this region, Moros y Moriscos en el Levante peninsular (Sharq al-Andalus): introducción bibliográfica, comp. M(KEL DE EPALZA et alii (Alicante: 1983). For the Kingdom of Aragon proper, the standard work is still J. M. LACARRA. Aragón en el pasado (Madrid: 1972) and especially his «intróduccion al estudio de los mudéjares aragoneses", Aragón en la edad media, II 11979), 7-22. See also M. L. LEDESMA, Los mudéjares en Aragón, a booklet (Zaragoza: 1979). General works on Spanish Mudejars, and a range of specialized bibliography for Jaume's reigns, will be found in R. I. BURNS, Islam under the Crusaders: Colonial Survival in the Thirteenth-Century Kingdom of Valencia (Princeton: 1973), and his Muslims, Christians and Jews in the Crusader Kingdom of Valencia: Societies in Symbiosis (Cambridge, Eng.: 1984 and 1986).

(2) AMBROSIO HUICI MIRANDA ed., Colección diplomática de Jaime l, el Conquistador, 3 vols in 6 (Valencia: 1916-1922).

(3) M. D. CABANES PECOURT ed., Documentos de Jaime / de Aragón, 4 vols. to date (Valencia: $1976 \mathrm{ff}$ ) 
then, 12 or approximately ten percent make a substantial and non-formulaic mention of Mudejars. The temporal span is unequal and random. One charter is from 1218, two from 1221, one from 1224, six from 1225 , and one each from 1226 and 1227 .

The content displays wide variety. Since standard Medieval typologies are of little use to the historian, save for the study of archival procedure or the notarial mentality, a retrospective functional scheme must suffice for the purposes of this paper (4). Two are Truce of God documents. One is a charter for the Knights Hospitaller. Two deal with ecclesiastical tithes and first fruits. Six relate to land grants within the upland Kingdom of Aragon and the coastal County of Barcelona. Four are pre-crusade grants of property within the Islamic region of Valencia. Ecclesiastical matters are prominent. Four documents concern Bishop Pons of Tortosa. One is for Bishop Sancho of Aragonese Zaragoza. Another is for Pere Tàrrega the prior of Poblet monastery. Yet another is addressed to a military-religious Order, the Hospitallers. These last seven documents total 51 percent of the overall sample, showing the weight of church affairs in the whole. Three documents or 25 percent concern secular lords.

From a geographical or more precisely regional point of view, the Crown or Realms of Aragon consisted mostly of three and later five separate constitutional entities, united only in the dynastic person of Jaume the Conqueror (5). Three of our documents are general, without regional orientation. Four concern then-Islamic Valencia and specifically the city of Peñíscola. Three are comital, two for Tortosa and one for Valencian Chivert. Three more touch the Kingdom of Aragon at Zaragoza, Bardallur and Cervera. The location of the sovereign in a given document's dateline is also a factor for interpreting its category, with Jaume validating instruments at Daroca, Huesca, and Zaragoza (all in Aragón), Pertusa in Catalonia, and Peñíscola in Islamic Valencia. Here the question of chancery practice arises. Could the crown notaries use the roval seal in the sovereign's absence? Probably so, during these early days of Jaume when the court or curia was small and traditionally itinerant. As for the upland kingdom of Aragon proper, by 1200 clusters of Mudejars formed a key element on the agricultural estates of the Aragonese barons along the Ebro River all the way down toward the sea. Tortosa in Catalonia, near the Ebro's mouth, lay along the northern border of Islamic Valencia and was a Mudejar Muslim frontier (6).

(4) For a review and analysis of such typologies see R. I. BURNS, Society and Documentation in Crusader Valencia (Princeton: 1985), ch. 21. See also A. M. ARAGÓ CABANAS and JOSEP TRENCHS ODENA "Las escribanías reales catalano-aragonesas de Ramón Berenguer IV a la minoría de Jaime ln, Revista de archivos, bibliotecas, y museos, LXXX (1977), 439-442.

(5) For background and bibliography see now THOMAS BISSON, The Medieval Crown of Aragon: A Short History (Oxford: 1986)

(6) LACARRA, "Mudéjares», pp. 10-13. 


\section{Mudejars in the Truce of God}

King Jaume's stormy early years elicited eleven proclamations of the Truce of God within sixteen years. At the Corts or parliament of Barcelona in 1228 , Jaume himself described this period as a time when "l came to you a child of six and a half years, and found Aragón and Catalonia in confusion, man fighting against man and not agreeing on anything" (7). The four Truces of God seem to have remedied this situation only temporarily. Two of them specifically mention Mudejars. The first mention comes from the Corts at Villafranca in 1218. This document proclamed a Peace, discussing such general matters as the church, clerics, and ecclesiastical property. It then decreed: "ltem, under the Peace are all Jews and Saracens, those to wit who live under the trust and ruling custody in Catalonia, and all their movable and real property." (8). This decree was repeated verbatim in 1225 at the Corts of Tortosa, just before the assault against Islamic Peñiscola. It assumes that subject Muslims owned their own property, and implies that they were somehow threatened in person and property $(9)$.

When the baronage was at war, one lord would often attack the Muslim or Christian tenants of his enemy. That was the easiest way to hurt one's opponent while avoiding both a risky battle and a costly time-consuming siege. Thus King Jaume's autobiography, the Llibre dels feits, tells how in 1219, during civil strife in Aragón, Don Rodrigo Lizana captured Don Lop de Albero with his castle of Albero and 10.000 cafises of grain, "besides doing him other harm, as well to Christian as to Saracen inhabitants of Albero, and all those who were with us thought the thing ill-done and also all the Aragonese." (10). This strategy for avoiding battles was employed in 1223 by En Guillem de Montcada against En Nunyo's holdings in Roussillon, by "wasting the land". En Nunyo was so distressed by the strategy that, while at Huesca, he begged the young king's intervention, pledging for arbitration the whole of his own holdings and those of his vassals in Roussillon (11). It is clear that a Truce of God was desirable not only generally for reasons of peace but also specifically because the Mudejar communities had no ultimate protection. Muslims had to the mentioned separately, since a Truce of God involved peace between various bodies - lords and lords, lords and church, lords and towns, Christians and Jews, or Christians and entities involving Mudejars (12).

\section{Mudejars: Tithes and First Fruits}

Tithes and first fruit were traditional taxes paid to the church by Christians annually, or by Muslims on land purchased or acquired from Christians.

\footnotetext{
(7) JAUME I, El/libre dels feits, in FERRAN SOLDEVILA ed, Les quatre grans cróniques (Barcelona: 1971 ) ch. 48.

(8) HUICl, Colección, doc. 9, p. 36, Viltafranca Corts, 24 June 1218

(9) lbid, doc. 67, p. 140

(10) Llibre dels feits, ch. 15

(11) lbid., ch. 21

(12) LACARRA, "Mudéjares", passim.
} 
Tithes rarely amounted to a full ten percent, and rural areas often paid them in kind rather than coin (13). The first tithe document in our series settled a problem in upland Aragon in the diocese of Zaragoza. The king was responding to repeated complaints by the diocese that lords of lands worked by Mudejars were not paying tithes and other fees. After diligent counsel from his barons at Zaragoza in 1221. King Jaume gave full power and license to seize the tithes from those farms held originally by Christian title. This involved "Saracens who bought, or held and received, from Christians farms to operate, from which the holy church of God and its ministers were accustomed to have tithes and such». The interrupted or transferred title here indicates a stratum of prosperous Mudejars buying land from Christians, and other Mudejars taking up lands granted to them as owner-settlers under a contractual arrangement atractive to a land-poor lord (14)

King Jaume hoped to avoid such problems in Tortosa. In 1224 he told Bishop Pons there that the Tortosan diocese could have the tithes and first fruits from rents "which the Christians receive from the Saracens" on produce, livestock, fishing, hunting, mining for gold and silver, or any other such activity (15). This was a serious issue. Similar problems had been encountered during the twelfth-century reconquest of the Ebro Valley, requiring royal intervention (16). Where royal authority was weak, and where church privileges and lands were under attack, recalcitrant nobles seized opportunities to avoid paying tithes, especially on personal profits from Mudejar rents. Apparently Jaume had to call a baronial council at Zaragoza to reviev the matter; this was not the council of regents for the king in his minority, but a meeting of Zaragoza's barons. The Zaragoza area had a large cluster of Mudejars who were essential to the prosperity of the larger estates. Hence the concern for order in this area by barons, crown, and church ("for we do not know how much injury the church has suffered in this region») (17).

In both cases it is clear that Jaume was supporting the church in its conflicts over Mudejar places for two reasons. First, the church was a pillar of support for royal power in Aragon and comital power in Catalonia. And secondly the church was a strong pillar in frontier areas. This tithe argument and policy was to be replicated on the Valencian frontier after its conquest. But Jaume gained his first experience with deploying the policy and using the church as a frontier institution during these earlier years. General support of the church out of motives of piety is a clear theme in the king's autobiography, of course; at this more prosaic level we see and alliance of altar and throne for very practical ends.

(13) R. I. BURNS, Medieval Colonialism: Postcrusade Exploitation of Islamic Valencia (Princeton: 1976), pp 190-191.

(14) HulCl, Colección, doc. 29, p. 69, Jaume to Bishop Sancho, 3 August 1221

(15) Ibid., doc. 52, pp. 115-120, Jaume to Bishop Pons, 27 April 1224

(16) This can be seen in J. M. LACARRA'S Mudejar documents among his «Documentos para el estudio de la reconquista y repoblación del valle del Ebron. Estudios de edad media de la corona de Aragón, II (1946), 469-574; III (1947-1948), 499-727; V (1952), 511-668.

(17) Jaume to Bishop Sancho, above in n. 14 


\section{Mudejars as Tenants}

Under this rubric we can examine the Mudejar in his most basic and diurnal aspect. Six documents concern Mudejars within the older regions, while five are pre-grants for unconquered Valencia. As with the Valencian documents, two of those six refer to the mosques of the Muslims. That some mosques were left to the community was both a requirement and a sign of its socio-religious health. Not only worship but business, education, and meetings of all kinds shared the mosque-space (18).

From both the Tortosa documents it is clear that mosques operated there. To gain support for the siege of Peñíscola, Jaume generously endowed his fellow besieger Bishop Pons of Tortosa (19). He also confirmed a royal predecessor's gift of "the mosques and their possessions and all cemeteries of the Saracens» (20). In the event of a negotiated and privileged surrender, of course, certain mosques would then have been exempted to the Muslim communities remaining. Income-producing properties (the waqf or foundation) maintained each mosque, much as Christian benefices might help support a church. Cemeteries were also a feature of this religious complex. Such institutions were important to the Mudejars, as providing continuity as well as context to their society.

The situation at Peñiscola soon became perilous for the Christian army (21). Of the six documents from Peñíscola in our Mudejar grouping, it is significant that none display the presence of any military Order among the witness-lists. Bishop Sancho of Zaragoza and his brother, both supported by the king in 1221, were now absent in his need (22). Only Bishop Pons of Tortosa seems to have been of help to the king at this point. With inadequate land and sea forces, Jaume nevertheless persisted in carrying out his ill-advised attempt to be a conquering crusader-king in the image of his father King Pere, as well as to stop the civil wars in Aragon. Pons himself may have been involved only because Peñíscola was so close to Tortosa that he could thus easily enlarge his diocese (23). By September the situation looked so grim that the king gave another grant of full control over the religious establishments of the expanding Tortosa diocese: "all mosques and their possessions, and the houses of the muezzins and their possesions", and "all the cemeteries of the Saracens within the limits of the diocese of Tortosas (24). Keeping in mind the numerical preponderance of Mudejars in these regions, the grant must have given the bishop great importance in the Mudejar community.

\footnotetext{
(18) See BURNS, Islam, ch. 9 on mosques and religious properties.

(19) R. 1. BURNS, The Crusader Kingdom of Valencia: Reconstruction on a Thirteenth-Century Frontier, 2 vols. (Cambridge, Mass: : 1967), I, 43.

(20) HUICl, Colección, doc. 52, pp. 119-120. Jaume to Bishop Pons, 27 April 1224.

(21) The documents cited here bear this out despite Jaume's reference to the Peñíscola campaign in Llibre. ch. 25

(22) Libre, ch. 25.

(23) BURNS, Crusader Kingdom of Valencia, 1, 43

(24) $\mathrm{HUICl}$, Colección, doc. 71, p. 150, Jaume to Bishop Pons, 3 September 1225
} 
The king's siege of Peñíscola was the occasion for two other notices about Mudejars later that same month. the first went to Pere Tàrega the prior of Poblet monastery, who received Azmet a black Muslim and Azmet's properties in Cervera, including lands, houses, and everything else the Muslim held in the town and countryside (25). A second grant involved Islamic Chivert in Valencia, when conquered in the future, implying control as well of its Mudejar tenants (26). A grant to Don Ladrón in 1227 at Bardallur in Aragon included in its formulas the Mudejar tenants (27).

Within the king's older realms, Mudejars appear in situations ranging from control by a bishop-lord as at Tortosa to an apparently freer or anyway royal status elsewhere in Catalonia. Mudejars possessed their properties and were a valued commodity. For Christian owners, Mudejar land in the Ebro was obviously a stepping-stone to prosperity. Similar conclusions can be drawn from the pre-conquest grants for Valencia. Our collection has four, which provide additional insight on the relation of Muslim/Mudejar connections between town and country. The connection seems close in Peñíscola, Cervera, and by inference Aragón, since the more important Muslims not only owned houses in the towns but various properties in the countrysides. Thus Pons of Tortosa was to get all the properties of Omar Ibn Sian within and outside of Peñíscola (28). Pere Tarrega got, in Cervera and its countryside, "the alfaqui Abdinaldela a Saracen of Peñíscola, and all the buildings or houses and farmhouses» and other properties which the alfaqui «owns in the city of Peñíscola and its territories and elsewhere, with fields, vineyards, gardens, lands, tenants, servants, wastelands and settled lands, with everything the aforementioned Saracen has» (29). Thus too the church fo St. Mary in the diocese of Tortosa got the holdings of Zuleima Bolahan, a Muslim, both inside and outside Peñíscola (30). Blasco de Alagón was granted any castle or town he could acquire in Islamic Valencia, with their holdings in any place (31).

All of this tells us three things. First, important Mudejar landowners were probably also important in the cities. Secondly, a Christian crusader could receive such a local system of interlocking personal properties intact. Third, it would seem that, since holdings were scattered inside and outside the cities, factions would probably not have an urban-versus-rural context; property paterns may thus have helped stabilize the social status quo and even the conquered Mudejar communities.

Out final document is a charter for the Knights Hospitaller in 1221 (32).

\footnotetext{
(25) Ibid., doc. 72, p. 151, Jaume to Pere Tàrrega, 5 September 1225.

(26) Ibid., doc. 62, p. 132-133, Jaume to Rodrigo Ximénez de Luesia, 21 September 1225

(27) Ibid, doc. 90, p. 178, Jaume to Lladro, 30 March 1227.

(28) Ibid., doc. 70, p. 147, Jaume to Bishop Pons, 13 August 1225

(29) Ibid., doc. 72, p. 151, Jaume to Pere Tàrrega, 5 September 1225

(30) lbid., dac. 73, p. 153, Jaume to Bishop Pons, 10 September 1225.

(31) Ibid., doc. 85, p. 173, Jaume to Blasco d'Alagón, 14 July 1226.

(32) Ibid., doc. 32, p. 73-75, Jaume to Hospitallers, 23 December 1221.
} 
It affects both Aragón and Catalonia, involving all the holdings of the Order in Jaume's realms. This privilege gives a sweeping exemption, from crown taxes forever, "to the men of the Hospital, namely Christians, Jews and Moors" (the Latin uses mauri rather than the usual sarracenil. The document's elaborate detail leaves no room for crown officials or tax-collectors to intervene, even in such moments of crisis when "we have burdened [people] with unusual exactions and demands». Crown officials ignoring this protection of the Order's Mudejars or others uincur the wrath of almighty God» and will be einterred with Judas» and other unsavory folk «in hell [ad Tartara], never to return».

These dozen documents raise significant questions and lead to important conclusions about Mudejars in this early period. Their status as a separate community, their high value to the Christian overlords, and the interaction between Christian and Mudejar all provided a blueprint for King Jaume on the eve of his conquest of Islamic Majorca and Valencia with their larger Mudejar problems. 